УДК 628.336.4:577.15

\title{
ПРИМЕНЕНИЕ ФЕРМЕНТНЫХ ТЕХНОЛОГИЙ ДЛЯ ПОВЫШЕНИЯ ЭКОЛОГИЧЕСКОЙ БЕЗОПАСНОСТИ ЦЕЛЛЮЛОЗНО-БУМАЖНОГО ПРОИЗВОДСТВА
}

\author{
(C) К.С. Болотова ${ }^{*}$, Е.В. Новожилов
}

\author{
Северный (Арктический) федеральный университет им. М.В. Ломоносова, \\ наб. Северной Двины, 17, Архангельск, 163002 (Россия), \\ e-mail: biotech@narfu.ru
}

Представлен аналитический обзор ферментных технологий, предназначенных для использования в целлюлозно-бумажном производстве (ЦБП). Высокая специфичность, экологическая безопасность ферментов делают их привлекательными реагентами для целлюлозно-бумажного производства. Ксиланазы, целлюлазы, липазы, эстеразы, амилазы, пектиназы рекомендуются или уже используются при производстве различных волокнистых полуфабрикатов. Введение в технологические процессы ферментов способствует селективному разрушению отдельных компонентов, что оказывает положительное влияние на состав технологических потоков и сточных вод, улучшает экологическую безопасность производства. Отдельные виды ферментов рекомендуются для микробиологического контроля образования биопленок, очистки сточных вод и обработки образующихся осадков. Ферментативные методы обеспечивают высокочувствительное и селективное определение различных веществ.

Ключевые слова: ферменты, целлюлозно-бумажное производство, экология, микробиологический контроль, биологическая очистка, осадок сточных вод, методы анализа.

Работа выполнена при финансовой поддержке базовой части государственного задания (проект «Биотехнология возобновляемых ресурсов растительного происхождения», САФУ им. М.В. Ломоносова, 2015 г.) Минобрнауки РФ.

\section{Введение}

Прикладное значение ферментов как реагентов для технологических процессов растет с привлечением внимания к проблемам экологии производства, развитию «зеленых» технологий и биотехнологий. Поиск, дизайн и применение биокатализаторов для использования в различных отраслях промышленности - главные тенденции развития современной биотехнологии. Ферменты - биокатализаторы химических процессов, представляют собой биологически активные белки, функционирующие в условиях, благоприятных для жизни организмов, из которых они выделены.

Основными продуцентами промышленных ферментных препаратов являются грибные культуры и бактерии. Наравне с выделением ферментов из диких штаммов широко развиваются технологии получения отдельных видов ферментов или целых ферментных комплексов на основе рекомбинантных микроорганизмов [1-3]. Это позволяет конструировать белки направленного каталитического действия, непосредственно изменяя генетический аппарат клетки-продуцента, а также регулировать объемы синтеза выбранного

Болотова Ксения Сергеевна - доцент кафедры биотехнологии и биотехнических систем, кандидат технических наук, e-mail: k.bolotova@narfu.ru Новожилов Евгений Всеволодович - заведующий кафедрой биотехнологии и биотехнических систем, доктор технических наук, профессор, e-mail: e.novozhilov@narfu.ru метаболита. Современные биотехнологии позволяют получать чистые ферментные препараты узкоспецифичного действия в количестве, достаточном для промышленного применения.

Белковая природа ферментов обеспечивает мягкие условия работы катализатора, позволяет

\footnotetext{
* Автор, с которым следует вести переписку.
} 
регулировать технологический процесс, варьируя режимные параметры производства, способствует ресурсо- и энергосбережению. Расширение специфичности и диапазона действия ферментных препаратов существенно повышает интерес к биокатализаторам как технологическим реагентам в различных отраслях промышленности, а биоразлагаемость на этапе утилизации, отсутствие токсичности улучшают экологическую безопасность производства.

Природное происхождение, высокая специфичность, экологическая безопасность ферментов делают их привлекательными реагентами для целлюлозно-бумажного производства (ЦБП). Ферментные технологии достаточно давно и успешно работают в ЦБП для интенсификации основных технологических процессов. Ферменты используются в качестве реагентов при отбелке сульфатной целлюлозы, размоле целлюлозных волокон, переработке макулатуры, удалении краски, для контроля смоляных загрязнений и в других направлениях.

Различные химикаты, применяемые в ЦБП, в ряде случаев могут быть полностью заменены на ферменты, или их действие дополнено действием ферментов. Амилазы, ксиланазы, целлюлазы, липазы, эстеразы, протеазы - все эти ферменты рекомендуются к использованию или уже используются при подготовке различных волокнистых полуфабрикатов к производству бумаги и картона [4-8]. Для ферментативной обработки характерны мягкие условия воздействия, очень маленькие расходы ферментных препаратов, отсутствие образования побочных продуктов, но требуется определенное время контакта с субстратом для эффективного действия ферментов. В качестве вспомогательных реагентов ферменты рекомендуют для микробиологического контроля обрастания технологического оборудования, на стадии переработки сточных вод и образующихся осадков.

Роль ферментов в улучшении экологической ситуации на предприятиях ЦБП может заключаться в следующем:

- замещение частично или полностью дорогих или вредных и опасных химикатов, таких как хлорсодержащие соединения, окислители, щелочи и кислоты;

- уменьшение образования токсичных хлорорганических соединений;

- снижение расхода биологически трудно разлагаемых веществ, таких как синтетические поверхностно-активные вещества (ПАВ), полимеры, предназначенные для ускорения обезвоживания массы и улучшения прочности бумаги;

- разрушение части компонентов оборотных и сточных вод (загрязнений) до низкомолекулярных и легко биологически разлагаемых продуктов;

- разрушение биологических веществ, образующихся в процессе производства за счет действия микроорганизмов (обрастаний, биопленок);

- определение характера и количества загрязнений методами, основанными на специфическом действии ферментов на отдельные компоненты оборотных и сточных вод, осадков после биологической очистки.

\section{Аналитический обзор}

\section{Улучшение экологии при введении ферментов в технологические процессы целлюлозно- бумажного производства}

Введение ферментов в технологические процессы ЦБП способствует селективному разрушению отдельных компонентов, что оказывает непосредственное влияние на состав оборотных и сточных вод. При этом не исключается сохранение их активности в технологических потоках, направляемых на стадию биологической очистки. Во многих случаях ферментативная деструкция дает растворимые продукты с меньшей молекулярной массой и, соответственно, более легкой биоразлагаемостью микроорганизмами активного ила.

Многие предприятия, производящие беленую сульфатную целлюлозу, используют ксиланазы. Обработка целлюлозы ксиланазами перед отбелкой интенсифицирует удаление лигнина и позволяет использовать меньшее количество делигнифицирующих и отбеливающих химикатов, в том числе хлорсодержащих реагентов. Эта технология успешно используется на предприятиях России [9].

Механизм действия ксиланаз и технология ксиланазной предобработки сульфатной целлюлозы достаточно хорошо изучены и подробно рассмотрены в работах $[6,10-14]$. Важную роль отводят частичной деструкции сорбированного ксилана, что обеспечивает большую доступность лигнина целлюлозы к действию реагентов. Для улучшения белимости целлюлозы достаточно удалить незначительную часть - менее 
$10 \%$ остаточного ксилана сульфатной целлюлозы [11]. Считается, что переход остаточного лигнина в раствор усиливается после разрушения связей между ксиланом и лигнином. Удаление некоторой части лигнина сульфатной целлюлозы прямо влияет на уменьшение расхода белящих реагентов. На делигнификацию целлюлозы указывают снижение числа каппа и увеличение содержания лигнина в фильтрате. Средняя молекулярная масса лигнина, растворенного после ферментной обработки, позволяет предположить, что происходит растворение лигноуглеводных комплексов с высоким содержанием лигнина [15].

В процессе отбелки гексенуроновые кислоты наряду с лигнином участвуют в реакциях с отбеливающими реагентами [16]. Снижение количества гексенуроновых кислот в целлюлозе после ксиланазной обработки происходит в результате удаления фрагментов ксилана, содержащих такие группы [17-19]. Олигосахариды с остатками гексенуроновых кислот были найдены в растворе после ксиланазной обработки целлюлозы из эвкалипта $[13,14]$.

Продуктами ферментативной деструкции ксилана являются водорастворимые олигосахариды различного состава [13-15]. Следует отметить, что разрушение ксилана под действием ксиланазы приводит к некоторому увеличению химических потерь и небольшому снижению выхода целлюлозы. Применение ксиланаз улучшает такие характеристики сточных вод производства беленой целлюлозы, как содержание органически связанного хлора и цветность.

По данным ряда авторов [20-22], обработка ксиланазами сульфатной целлюлозы способствует ускорению размола. Показано [20, 21], что действие ксиланазы дает значительную внешнюю фибрилляцию волокон беленой сульфатной целлюлозы и снижает потребление энергии на размол. Растворение углеводной части при размоле ферментативно обработанной целлюлозы было значительно ниже, когда использовались высокоочищенные ксиланазы, практически свободные от целлюлазной активности. В работе [22] минимальные потери выхода (0,53 кг/т целлюлозы) наблюдались при применении ксиланазы Pulpzyme HC, в то время как при использовании других препаратов ксиланаз они были в несколько раз больше и достигали уровня 2,91-4,59 кг/т целлюлозы. Удаление значительного количества ксилана нецелесообразно, так как связано не только со снижением выхода волокна, но и с возможной потерей прочности бумаги.

Для устранения смоляных затруднений применяются липазы. При производстве механических масс большое количество древесной смолы находится в виде суспензии в оборотных водах и может участвовать в образовании агрегатов, давать отложения на оборудовании или бумаге. Механические массы часто не промывают перед тем, как их направляют на производство бумаги. Присутствующие в рециркулирующей воде растворенные и коллоидные вещества, в состав которых входят полисахариды, лигнин, лигноуглеводные комплексы, пектины, смолистые вещества, уменьшают производительность бумагоделательной машины (БДМ) и ухудшают качество товарной продукции [23, 24]. Удаление смолы с использованием ферментов (липаз или лакказ) является весьма эффективным, так как, в отличие от многих других методов обессмоливания, ферменты разрушают компоненты смолы, что облегчает удаление продуктов деструкции экстрактивных веществ (ЭВ) и их последующее биоразложение. При этом ферментативная обработка вполне может быть использована вместе с другими способами борьбы со смоляными затруднениями.

Обработка липазами влияет на стабильность коллоидных веществ оборотных вод и их способность к осаждению на волокна и образованию отложений на оборудовании [25-28]. Чем больше концентрация смолистых веществ в оборотной воде, тем больше их осаждается на волокна. Добавление липазы приводило к практически полному гидролизу жиров с образованием соответствующего количества жирных кислот. Это вызывало увеличение содержания ЭВ в бумаге, но не влияло на прочность бумажного листа.

Лакказы - это ферменты, также подходящие для решения проблемы смоляных затруднений. Для удаления и разрушения смолы рекомендуется проводить обработку лакказой процессной воды [29]. ЭВ, которые остаются в массе и процессной воде, могут активно участвовать в реакциях с лакказой в качестве медиаторов [30]. Показано [31], что обработка оборотной воды культуральным фильтратом гриба Trametes versicolor, содержащим лакказную, липазную и целлюлазную активности, обеспечила деструкцию значительной части биологически трудно разлагаемых компонентов. Было разрушено более 90\% лигнанов, эфиров стиролов и триглицеридов, уменьшена на 40-60\% концентрация смоляных и жирных кислот.

Лакказы и пероксидазы предлагается применять на начальных стадиях отбелки для обработки или небеленой целлюлозы, или целлюлозы, делигнифицированной кислородом в щелочной среде [31-33]. Могут иметь место прямая делигнификация, т.е. разрушение и удаление остаточного лигнина целлюлозы, или модификация, облегчающая его дальнейшую деструкцию химикатами в процессе отбелки. 
Основная часть исследований делигнификации небеленой целлюлозы выполнена с лакказой и различными лакказа-медиаторными системами (ЛМС) [6, 7, 34]. В присутствии медиаторов деструкция лигнина усиливается и становится необратимой. Предполагалось, что стадия обработки ЛМС может заменить в схеме отбелки стадию кислородной делигнификации или стадию обработки озоном. Биодеградация лигнина окислительными ферментами способствует последующей отбелке целлюлозы. Однако окислительные ферменты успешно работают только при добавлении дорогих медиаторов, что является в настоящее время технологическим барьером.

Обработка лакказами на ранних стадиях технологического процесса оказывает дальнейшее воздействие на весь процесс производства бумаги. Ферментативная деструкция ЭВ благоприятно сказывается на производстве бумаги за счет уменьшения смоляных затруднений и соответствующего снижения расхода химикатов для борьбы с вредной смолой. Разрушение ЭВ под действием лакказы должно положительно сказаться на качестве сточных вод, уменьшить токсичность стоков и улучшить их очистку. Однако практического выхода это направление пока не получило и все еще находится в стадии изучения и лабораторных испытаний.

Улучшение бумагообразующих свойств - это основное направление ферментативной модификации целлюлозных волокон для ЦБП. Проведены многочисленные исследования с использованием различных ферментов, в основном целлюлаз, ксиланаз и лакказ. Ферментативную модификацию целлюлозных волокон, предназначенных для производства бумаги и картона, можно проводить как до размола, так и после него.

Большинство исследований, направленных на ускорение размола технической целлюлозы, проведено с целлюлазами $[6,7]$. Благоприятные изменения в свойствах волокон могут быть достигнуты короткой обработкой при относительно низкой концентрации ферментов. Модификация целлюлазами преследует цель подготовить волокна к механическому воздействию таким образом, чтобы уменьшить затраты энергии на размол при сохранении прочности индивидуальных волокон и минимальных потерях углеводной части. Эффект воздействия определяется прежде всего видом целлюлазы и ее расходом. Изменение свойств целлюлозы после ферментативной обработки целлюлазами связано с эрозией поверхности целлюлозных волокон, а также с частичным удалением поверхностных слоев клеточной стенки. Преимущественное удаление мелочи из волокнистой массы в процессе ферментативной обработки $[35,36]$ объясняется ее большей поверхностью и большей доступностью для действия фермента. При селективной ферментативной обработке длинноволокнистой фракции хвойной сульфатной целлюлозы потери выхода в виде перешедших в раствор продуктов деструкции составляли 0,2-0,3\% от волокна [37].

Для удаления типографской краски рекомендуются целлюлазы, ксиланазы и амилазы. Ферментное удаление краски является привлекательной альтернативой химическому способу, основанному на использовании для обработки щелочи, пероксида водорода, силиката натрия, хелатов [38, 39]. Целлюлазы и гемицеллюлазы облегчают отделение частиц краски, удаляя отдельные фибриллы и частично разрушая поверхность волокон [40-43]. Окрашенные частицы становятся меньше, что способствует отделению краски и тонера от волокна. Важным преимуществом применения $\alpha$-амилазы является то, что выход волокна в этом случае выше, чем при деинкинге с использованием целлюлаз и гемицеллюлаз. Это связано с отсутствием деградации мелочи и фибрилл на поверхности волокон, что уменьшает загрязнение сточных вод. Улучшение качества очистки сточных вод достигается также за счет исключения части химических ПАВ, трудно разлагаемых при биологической очистке.

При переработке вторичного бумажного сырья, содержащего лазерные чернила, только комбинированные химико-ферментативные процессы дают удовлетворительные результаты [41]. Ферментативный метод по сравнению с химическим способом обеспечивает более низкий расход химикатов и меньшее загрязнение процессной воды минеральными веществами.

Положительное влияние на улучшение водоотдачи массы на сетке БДМ оказывает применение целлюлаз или гемицеллюлаз [44]. Целлюлазы вызывают эффект «пилинга», связанный с удалением фибрилл с поверхности волокон [42]. При ограниченном воздействии, когда разрушаются только имеющие повышенную способность к водоудержанию отдельные фрагменты структуры волокон и часть мелочи (fines), улучшение дренажа массы происходит без уменьшения механической прочности бумаги. После отделения фильтрата из массы и его кислотного гидролиза в растворе были найдены не только глюкоза, но также манноза и ксилоза. Это объяснялось частичной деструкцией остаточных гемицеллюлоз: глюкоманнана и ксилана, из-за наличия в целлюлазных препаратах побочных гемицеллюлазных активностей [45]. Преимуществом селективно действующих целлюлаз является низкая гидролизующая способность, что суще- 
ственно снижает потери выхода волокна. Образование водорастворимых продуктов деструкции незначительно и при оптимальном расходе ферментов не превышает 0,1\% по сравнению с контролем [42].

Мелкое волокно из оборотных вод может быть выделено отстаиванием или фильтрованием в виде скопа. Обработка скопа целлюлазой значительно улучшает его обезвоживающую способность, о чем свидетельствует уменьшение степени помола на 6-15 ШР [46]. Потери волокна после такой обработки были небольшими, улучшение водоотдачи связано с разрушением мелочи и модификацией свойств мелкого волокна.

Представляет практический интерес ферментативная деградация пектиновых веществ, растворенных из механической массы $[47,48]$. Пектиновые вещества представляют собой комплекс веществ углеводного характера, включающий полигалактоуроновые кислоты, арабинан и галактан. В процессе щелочной пероксидной отбелки механической массы пектины деметилируются и растворяются в процессной воде. Пектиновые вещества увеличивают образование отложений, при удержании волокнами снижают прочность бумажного полотна во влажном состоянии, уменьшают белизну листа и прочность бумаги [48, 49]. Пектиновые кислоты заряжены отрицательно, что повышает катионную потребность механической массы. Однако после ферментативной деструкции макромолекул пектинов до небольших фрагментов (степень полимеризации ниже 7) такие олигомеры теряют способность присоединяться к катионным полимерам. В результате пектиназная обработка снижает катионную потребность в производстве термомеханической массы более чем на 40\%, соответственно, пропорционально уменьшается потребление химикатов в процессах производства бумаги [50, 51].

Современные тенденции к замыканию цикла водооборота ведут к накоплению в воде растворенных и коллоидных веществ, которые ухудшают обезвоживающую способность массы, снижают эффективность веществ, применяемых в качестве наполнителей и проклеивающих агентов, а также химикатов, используемых для удержания волокон. Непрерывное поступление микроорганизмов с воздухом, водой, волокнистыми видами сырья и химикатами приводит к специфическому микробиологическому равновесию в технологических потоках бумажной фабрики. Микробиологическая загрязненность технологических сред негативно влияет на качество тарного картона из макулатуры [52]. Накопление загрязнений в оборотной воде приводит к снижению прочностных характеристик продукции [50, 53].

При переработке вторичных волокон в оборотных водах накапливаются отработанный крахмал, упрочняющие и проклеивающие вещества, анионные загрязнения, липкие вещества, мелкое волокно. Оборотные воды добавляют для разволокнения макулатуры в гидроразбиватели, многократно используют для разбавления массы на различных этапах ее подготовки. Сообщалось, что концентрация растворенного крахмала в оборотной воде бумажных фабрик, перерабатывающих макулатуру, составляет от 30 до 100 мг/л, на некоторых предприятиях достигает 149-160 мг/л [54-56] и даже 1200 мг/л [57]. Для определения крахмала в растворе обычно применяют йодометрический метод, который дает заниженные результаты. Перспективны методы анализа растворенного крахмала, основанные на ферментативной деструкции $[58,59]$. Больше всего растворенного крахмала в технологических средах определяется по методике, представленной в работе [58].

Амилазы предлагается использовать на различных этапах производства бумаги. Ферментативное разрушение растворенного крахмала с последующим удалением продуктов его деструкции улучшает обезвоживание массы. Смесь амилолитических ферментов способна постепенно полностью деструктировать макромолекулы крахмала. Обработка смесью $\alpha$-амилазы и целлюлазы способствует ускорению фильтрования пробы промышленной оборотной воды, это большей частью обеспечивается разрушением коллоидных и растворенных веществ [46]. Кроме того, $\alpha$-амилаза может использоваться для деструкции крахмала, применяемого для покрытия офисной бумаги.

Ферментные технологии являются одним из наиболее эффективных решений проблемы клейких веществ. Опасность накопления липких загрязнений значительно возрастает при замыкании цикла водооборота макулатурных фабрик. В таких условиях предлагается применять эстеразы, которые разрушают клейкие вещества до более мелких и менее липких микрочастиц, делают их поверхность более гидрофильной. Это способствует предотвращению агломерации и лучшему удержанию загрязнений в массе. Эстеразы были успешно использованы при контроле клейких веществ на бумажных фабриках по переработке вторичного волокна $[44,60,61]$. В результате применения эстераз значительно сокращаются отложения и сокращается необходимость в химикатах для чистки полотна и частей бумагоделательных машин. 
Микробиологический контроль технологических потоков целлюлозно-бумажного производства

Перспективным направлением для применения ферментных препаратов в ЦБП являются микробиологический контроль загрязненности технологических потоков и борьба с биообрастаниями.

Микроорганизмы и выделяемые ими внеклеточные полимеры формируют структуру гликокаликса, включающую олиго- и полисахариды, гликолипиды и гликопротеиды, и могут вызывать серьезные проблемы, связанные с образованием биологических отложений (биопленок). Состав биопленки достаточно сложен из-за большого количества различных микроорганизмов и полимеров, вовлеченных в процесс ее образования. Биопленки вызывают обрастание трубопроводов и сбои в работе оборудования, влияют на режимные параметры процесса и загрязняют товарный продукт. В частности, нитчатые формы способны ассимилировать компоненты технологических сред, наращивать биомассу и забивать сетки и ленты оборудования [62].

Для борьбы с микробиологическим обрастанием рекомендуется применение биоцидов, ферментов, биодиспергаторов, бактериофагов [7]. Широкое применение биоцидов связано с их антимикробным или биостатическим действием на живые клетки биопленки. К биоцидам предъявляется ряд требований, включая действие в широком диапазоне $\mathrm{pH}$, отсутствие влияния на компоненты технологических сред и целлюлозу, широкий спектр действия в отношении разных видов микроорганизмов, экологическая безопасность, эффективность, невысокая стоимость препаратов $[63,64]$. Недостатками их использования являются способность некоторых микроорганизмов формировать резистентность к таким реагентам, неэффективность их действия, связанная со сложностью проникновения в объем биопленки при ее росте, и экологическая опасность при высоких расходах. Применение химических реагентов не обеспечивает комплексного воздействия и разрушения биопленок.

Альтернативным способом микробиологического контроля на предприятии могут быть ферментные препараты. Ферменты действуют на живые клеточные системы и модифицируют их компоненты для микробиологической конверсии или ассимиляции. Указывается [7], что для контроля биопленок могут быть востребованы промышленные препараты амилаз, целлюлаз, липаз, протеаз и ксиланаз с молекулярной массой от 20 до 250 кДа. Хорошие результаты для предотвращения образования биопленки в технологии ЦБП показали пектиназы, леваназы и ферменты класса трансфераз [7, 65, 66]. Эффективность препаратов непосредственно связана с типом полимера, составляющего основную массу биопленки. Учитывая строение клеточной стенки микроорганизмов биопленки, эффективным также оказалось действие на нее гидролитических ферментов с глюканазной и протеазной активностями.

В качестве средств микробиологического контроля исследованы некоторые ферменты и их смеси, в том числе в сочетании с биоцидами и биодиспергаторами. Эффективными оказались протеазы, эстеразы, целлюлазы, $\beta$-глюканазы, лизоцим, гемицеллюлазы, амилазы, пуллуланазы [5, 67-69]. Показано [62], что применение леваназы для разрушения полимера левана облегчает проникание биоцидов в биопленку, что снижает затраты на химикаты. Альгинатная лиаза и маннаназа вызывают разрушение клеточных стенок [5, 71, 72]. В работах $[73,74]$ для гидролиза клеточных стенок дрожжей и плесневых грибов рекомендуется применять ферментный комплекс, включающий хитиназу, протеазу и $\beta$-глюканазу.

Технологии, основанные на совместном использовании ферментов и биоцидов, обеспечивают существенное сокращение микробиологической популяции при снижении дозировки химиката (по разным источникам, на 15-50\%) и, следовательно, повышение экологической безопасности процесса.

\section{Использование ферментов при очистке сточных вод}

ЦБП считается отраслью, оказывающей крайне негативное воздействие на окружающую среду, решение проблемы очистки сточных вод для ЦБП является весьма актуальной задачей. В составе сточных вод содержатся взвешенные вещества (частички коры, наполнители, волокна), органические вещества (фенолы, углеводы, смоляные и жирные кислоты, метанол, скипидар, формальдегид), минеральные вещества $[75,76]$. Многокомпонентный состав и токсичность загрязнений сточных вод ЦБП требуют необходимости создания сложных, многостадийных схем и использования разнообразных систем очистки воды.

Основу промышленной технологии очистки сточных вод составляет биологическое окисление загрязнений [77]. Широко распространенным способом очистки является биохимический метод с использованием биореакторов с прикрепленной микрофлорой и аэротенков [77, 78]. Окисление загрязняющих веществ сточной жидкости микроорганизмами активного ила происходит за счет выделяемых ими ферментов, главным образом за счет дегидрогеназ. Суммарная активность данных ферментов является ключевым 
показателем для оценки физиологического и функционального состояния микроорганизмов, характеризует скорость и глубину процессов биологического окисления.

Для определения дегидрогеназной активности предложена методика, основанная на восстановлении индикатора 2,3,5-трифенилтетразолия с последующим фотометрическим анализом полученных растворов $[79,80]$. Однако эта методика трудоемкая и длительная - на анализ требуется около 1,5 ч. Недавно разработан экспресс-способ количественного определения дегидрогеназной активности микроорганизмов [81, 82], в котором в качестве акцептора водорода выбран метиленовый синий. Основным преимуществом данного способа является оперативность - длительность анализа не превышает 10 мин. О дегидрогеназной активности микроорганизмов судят по изменению концентрации метиленового синего, которую непрерывно регистрируют оптическим способом с помощью специально изготовленного устройства [83].

Природное происхождение и специфичность таких технологических реагентов, как ферментные препараты, позволяют избежать вторичного загрязнения сточных вод побочными продуктами. Такие препараты являются экологически безопасными и биологически разлагаемыми, а экономическую эффективность процесса определяют их качество и дозировка.

Учитывая особенности технологии ЦБП, разрабатывают ферментные препараты, специально ориентированные на очистку сточных вод. На стадии биологической очистки ферментные технологии обеспечивают процессы дехлорирования, снижения цветности воды, разрушения крахмала, удаления фенольных и лигнинных веществ [6, 7].

Фенольные соединения - продукты деструкции лигнина - в системе сточных вод ЦБП являются основными источниками цветности, АОХ и диоксинов. Для таких потоков рекомендуют грибные лакказы и пероксидазы [7]. Ферменты, продуцируемые грибом Phanerochaete chrysosporium, способствуют разрушению лигнина и обеспечивают начальную стадию окисления бенз(а)пирена, минерализацию антрацена. Окисление многих орто- и парадифенолов, а также некоторых монофенолов и мета-дифенолов катализируется лакказами [84].

Пероксидазы, полученные с помощью штамма Streptomyces albus ATCC 3005, проявляют высокую активность и способны катализировать реакции деструкции ряда соединений, включая 2,4-дихлорфенол, L-3,4-дигидроксифенилаланин, 2,4,5-трихлорфенол, в присутствии пероксида водорода [53]. Исследована [85] обработка технологических потоков, содержащих растворенные фрагменты лигнина, такими препаратами, как картофельная полифенолоксидаза и система пероксидаза хрена/пероксид водорода. Для обоих случаев характерна полимеризация фрагментов лигнина, улучшающая его осаждение из раствора.

Выделены четыре бактериальных штамма из шлама ЦБП, один из щелочетолерантных штаммов рода Bacillus был эффективен в отношении снижения цветности сточных вод и удаления лигнина [86]. Продуценты рода Bacillus обладают способностью к выделению термостабильной ксиланазы, вызывающей обесцвечивание стойких красителей в широкой области $\mathrm{pH}$ [87]. Два вида Aspergillus fumigatus и Aspergillus flavus, выделенные из шлама ЦБП, а также род Thelephora показали способность к снижению цветности сточных вод [88, 89].

Применение грибных лакказ (продуценты Rhizoctonia praticola и Trametes versicolor), а также пероксидазы хрена и тирозиназы [90] привело к удалению загрязнений фенольной природы за счет их полимеризации. Установлена зависимость степени удаления галогенированных фенолов от содержания хлора и молекулярной массы заместителя. Образование хлорид-ионов в процессе полимеризации достигало $20 \%$ от начального содержания хлора в молекулах 2,4-дихлорфенолов. Дехлорирование благоприятно влияло на общую детоксикацию потока. Лигнинпероксидазы (лигниназы), полученные с помощью гриба Phanerochaete chrysosporium, также могут разрушать хлорфенолы [91].

В ряде работ $[91,92]$ изучена возможность использования некоторых грибов белой гнили при очистке стоков после отбелки целлюлозы. Способность производить лакказы, лигнинпероксидазы, марганецзависимые пероксидазы и снижать цветность сточных вод показали виды Phlebia radiate, Phanerochaete chrvsosporium, Merulius (Phlebia) tremellosus.

В обзоре [94] обсуждается возможность использования лакказ и их комплексов на различных стадиях ЦБП. Это обусловлено лигнолитическим и полимеризующим действием ферментов данного типа на соединения фенольной природы. Применение лакказ-медиаторных систем, где в качестве медиаторов выступают 1-гидроксибензотриазол и другие соединения, интенсифицирует как аэробное, так и анаэробное биоразложение и снижает токсичность сточных вод сульфатного производства $[6,93,94]$. 
Системы лакказа/лакказа - медиаторная система позволяют удалять из сточной воды смолистые вещества, фенольные соединения, красители. В работе [95] показано влияние лакказы на увеличение молекулярной массы растворенного лигнина, что способствует его последующему осаждению. После обработки лакказой основная масса моно- и дихлорфенолов осаждается из потоков со стадии отбелки. При обработке высокомолекулярной фракции лигносульфонатов лакказы совместно с глюкозоксидазами обеспечивают эффективную деполимеризацию [96].

На стадии подготовки сточных вод предложено использовать комплекс ферментов, включающий $\alpha$-амилазу, протеазу и $\beta$-глюканазу [5-7, 97]. При этом предлагается применять непосредственно продуценты ферментов [98]. Использование грибов Trametes versicolor (штамм В7) в составе пеллет при обработке стоков небольшого целлюлозного комбината позволило исключить проблему загрязнения при рециклинге биомассы. Такие пеллеты обеспечили снижение цветности потока на 92\% и комплексное удаление углеводов, снизив химическое потребление кислорода (ХПК) на $69 \%$.

С учетом комплексного подхода к технологии ЦБП, создания максимально замкнутого водооборота и повышения качества очистки сточных вод, ферменты (лакказы, целлюлазы, липазы) используют в комплексе с микроорганизмами (в частности, вида Trametes versicolor) для разложения загрязнений и снижения цветности потоков. Такая биокомпозиция влияет на полимеризацию низкомолекулярных фенольных соединений. Циркуляция ферментов в системе оборотной воды позволяет непрерывно разрушать растворенные и коллоидные вещества, а ферментные системы грибных культур примерно на 90\% снижают содержание лигнанов и веществ со сложноэфирными связями [99]. В процессах детоксикации и переработки фенолсодержащих потоков эффективны оксидоредуктазы и лиазы [100].

Специфичность действия ферментов в системе биологической очистки сточных вод позволяет улучшить жизнедеятельность микроорганизмов активного ила. Поддержание искусственной экосистемы в очистных сооружениях (аэро- и метантенков) связано с детоксикацией и переводом неассимилируемых микроорганизмами соединений в доступную для потребления форму. Это улучшает качество среды для развития микроорганизмов, повышает эффективность работы активного ила, снижает количество загрязнений. Биомасса активного ила в этих условиях быстро растет, но, с другой стороны, при этом образуются значительные объемы биологического отхода производства в виде осадка сточных вод.

\section{Использование ферментов при переработке осадков, образующихся на целлюлозно-бумажных} предприятиях и бумажных фабриках

Технология биологической очистки большинства предприятий ЦБП предполагает совместную переработку осадков первичных отстойников и активного ила. Получаемая в результате смесь осадков обладает плохой водоотдачей, что объясняется содержанием большей части влаги в связанном состоянии. Эта особенность осадка сточных вод обусловливает основную проблему его утилизации, требующую новых подходов. Такие возможности открывают, в частности, ферментные технологии [5-7].

Осадок первичных отстойников представляет собой суспензию взвешенных веществ влажностью 95$97 \%$ и с содержанием органических веществ 60-75\%. pН такого осадка находится в пределах 6,5-7,5 [101]. Зольность волокносодержащего осадка, выделяемого при механической очистке, составляет для бумажных фабрик 30-50\%, целлюлозно-бумажных комбинатов - 20-40\%, целлюлозных заводов - 5-15\% [102].

Доля активного ила в составе осадков сточных вод ЦБП находится в диапазоне 65-75\% [103, 104]. Состав микробиологических осадков сточных вод (OCB) колеблется в широких пределах в зависимости от отраслевой направленности предприятия и отличается как по физико-механическим свойствам, так и по химическому составу. Около 85-90\% сухого вещества клеток ила составляют органические вещества.

Активный ил представляет собой сложный комплекс микроорганизмов, водорослей, грибов, простейших и других организмов. Многовидовой состав активного ила обусловливает развитие у микроорганизмов приспособлений и специальных клеточных функций, направленных на подавление жизнедеятельности конкурирующих видов. Для защиты от неблагоприятных воздействий и хищников, для прикрепления к поверхности клетки выделяют в среду сильнооводненные биополимеры (слизь). Причем биомасса клеток составляет лишь 15-20\% объема хлопьев зооглея. Природа биополимеров аналогична составу биопленок. Состав слизи зависит от вида микроорганизма, но обычно содержит гликопротеины и полисахариды. В составе биополимеров активного ила ЦБП обнаружена поли- $\beta$-гидроксимасляная кислота в количестве $12-55 \%$ от массы сухих веществ ила [105]. 
Слизь, окружающая микроорганизмы, оказывает существенное влияние на водоотдачу осадка. С одной стороны, она способствует флокуляции клеток активного ила, с другой - биополимеры удерживают значительное количество воды. В состав осадка переходят специфические загрязнения, содержащиеся в сточных водах предприятий ЦБП: волокна, наполнители, пигменты, проклеивающие вещества, красители и др. Физико-химические свойства этих соединений определяют свойства осадка и влияют на его переработку. Это приводит к сохранению высокой влажности осадка после выделения и к сложностям при его обезвоживании.

Входящие в состав осадка целлюлозные волокна играют роль носителей, сорбирующих клетки ила на своей поверхности и способствуют осаждению на стадии уплотнения. Однако такой эффект дает только достаточно длинное волокно. Мелкое волокно, например скоп, отделяемый при переработке макулатурной массы, наоборот, способен значительно ухудшать водоотдачу, набухая в процессе уплотнения и образуя рыхлые структуры, снижающие эффективность обезвоживания. В ряде источников [5-7] отмечается улучшение обезвоживания целлюлозной массы при модификации поверхности целлюлозных волокон за счет ферментативной обработки. Применение целлюлаз может привести к ускорению водоотдачи коротковолокнистой фракции отходов макулатурной массы.

Биологическая очистка сточных вод не позволяет в полной мере удалить такие соединения, как лигнин, скипидар, смоляные кислоты. Масла и жиры нарушают процессы коагуляции клеток. Применение в этом случае специфичных ферментов приводит к улучшению биологической очистки, улучшению обезвоживания образующегося при этом осадка $[106,107]$. На процесс хлопьеобразования ила существенно влияет солевой состав. Кроме того, хлопья ила способны накапливать соединения металлов, в том числе тяжелых, а также токсичные вещества, вызывающие отмирание микроорганизмов. Это приводит к изменению свойств ила, увеличению коллоидных и мелкодисперстных частиц и, соответственно, ухудшению обезвоживания. Водоотдача осадка возрастает с повышением размера содержащихся в нем частиц [101]. Первичный осадок содержит 50-88\% частиц размером менее 1 мм, а вторичный - 98\% таких частиц (по сухому веществу). В результате влажность осадка, направляемого на стадию механического обезвоживания, достигает 97-98\% [101, 105, 108, 109]. Добавки коагулянтов и флокулянтов на стадии обезвоживания осадка сточных вод (ОСВ) не всегда оправданы в связи с их большими дозировками и стоимостью.

Учитывая липопротеиновую структуру клеточной оболочки, предлагалась ферментная обработка ОСВ липазой и протеазой $[67,110]$. Для интенсификации окислительного процесса при обезвоживании как муниципальных, так и промышленных ОСВ применялась совместная обработка пероксидазой и целлюлолитическим ферментом (эндоглюконазной активности) совместно с флокулянтом. Также для этих целей применяют протеазы, гликопротеиназы, липазы, $\alpha$-амилазы, $\beta$-глюканазы, гемицеллюлазы, ламинариназы [97, 111].

Осадок бумажных фабрик отличается высоким содержанием крахмала, наличием краски, минеральных наполнителей [112]. Предложено использовать $\alpha$-амилазы для улучшения обезвоживания крахмалосодержащих отходов бумажного производства.

Основным направлением утилизации ОСВ в настоящее время является вывоз в отвал. Создание на основе твердых бытовых отходов коммерческих продуктов не всегда возможно, в России не более $10 \%$ подвергаются вторичной переработке [113]. Предлагаются методы получения из осадков товарных видов продукции. Среди них - ферментативный гидролиз осадков бумажных фабрик комплексом целлюлаз с последующим производством этанола [114-117].

Целлюлозные волокна оказывают положительное действие в процессе механического обезвоживания, улучшая структурообразующие свойства формирующегося кека. Армирующий эффект, проявляемый волокном в структуре осадка, обеспечивает удержание компонентов осадка при обезвоживании под давлением. Однако снижение потерь волокна - это общая тенденция совершенствования технологии, его содержание в сточных водах и ОСВ будет постоянно уменьшаться. Это может привести и уже приводит к ухудшению обезвоживания и увеличению конечной влажности кека. В таком случае перспективно внесение в осадок целлюлозосодержащих добавок. На основании такого подхода разработаны новые технологии переработки осадка, в том числе высокоинтенсивные безреагентные способы его обезвоживания и утилизации в качестве биотоплива [118].

Еще одним направлением улучшения качества очистки сточных вод и снижения объема образующихся осадков является микроферментная технология [119]. Она основана на совместном применении подобранной популяции микроорганизмов и комплекса ферментов, ориентированных на переработку отхо- 
дов и их утилизацию. Наличие в препарате микроорганизмов способствует естественному разложению осадков сточных вод, а ферменты специфично катализируют реакции распада органической составляющей осадка. Разработаны препараты как для очистки сточных вод, так и для утилизации осадков с получением компостов или удобрений.

Биоразложение веществ, входящих в состав твердых отходов, достигается за счет деградирующего действия ферментных систем микроорганизмов окружающей среды. Эффективность ферментативного расщепления биополимеров зависит от класса полимера, состава осадка, параметров производственного процесса. Подбор ферментного комплекса и его расхода требует индивидуального подхода.

Целлюлоза в современном мире остается наиболее востребованным биополимером, широко применяемым в производстве упаковочных материалов. Ускорение и интенсификация биоразлагаемости таких отходов могут быть достигнуты с применением целлюлолитических ферментов, разрушающих прочную надмолекулярную структуру целлюлозы [120]. Биоразлагаемость полимеров может быть обеспечена за счет введения в материал добавок, в качестве которых рекомендуются природные полимеры: крахмал, целлюлоза, хитозан, белки. Перспективными являются получение полиэфиров гидроксикарбоновых кислот, а также придание биоразлагаемости промышленным многотоннажным полимерам за счет введения добавок, ускоряющих фоторазложение, инициирующих распад основного полимера, или путем направленного синтеза таких биодеградируемых материалов [121].

Проблема биоразложения твердых отходов особенно актуальна для северных территорий, где гидролитические процессы протекают крайне медленно. Ферментативное разложение является естественным природным процессом для экосистем влажных северных регионов с низкими температурными параметрами, оно не приводит ко вторичному загрязнению окружающей среды. Накопление целлюлозосодержащих отходов требует изучения механизмов биоразложения и оценки эффективности ферментативного гидролиза и микробиологического разложения, ведущую роль в этих процессах играют гидролазы.

\section{Ферментативные методы анализа}

Ферментативные методы обеспечивают высокочувствительное и селективное определение различных веществ, в том числе физиологически активных. Разработка ферментативных систем, позволяющих усовершенствовать действующие методы и предложить новые варианты анализа, - это перспективное направление современной биотехнологии.

Ранее уже упоминалась методика определения растворенного крахмала, основанная на использовании амилолитических ферментов [58]. Она включает предварительную подготовку пробы воды, полный ферментативный гидролиз крахмалопродуктов и определение образовавшейся глюкозы известными методами. Использование данной методики дает возможность с высокой точностью контролировать содержание крахмала в оборотных и сточных водах бумажных фабрик.

Широкие возможности ферментов как аналитических реагентов целесообразно использовать для оценки активности микроорганизмов ила. Для анализа состава многокомпонентных смесей могут быть использованы различные типы ферментов, как обладающие узкоспецифичным действием, так и способные определять отдельные группы загрязняющих веществ родственной природы, например фенольные вещества. Ферменты предлагается использовать для быстрого анализа биоразлагаемости материалов [122-125].

Микробиологический контроль на сооружениях биологической очистки может осуществляться с применением ферментативных реакций. Определение дегидрогеназной активности микроорганизмов активного ила по ранее упомянутой методике [83] позволяет выявить виды промышленных сточных вод, негативно влияющих на работу очистных сооружений в целом [126-129].

Показано [130], что активность каталаз промышленных илов в процессе продленной аэрации зависит от возраста, стадии развития и физиологии микроорганизмов смешанной популяции и ряда других факторов. Высокая чувствительность каталаз к изменению условий окружающей среды обусловливает перспективность использования показателя каталазной активности для оценки состояния биоценоза промышленных илов зрелого возраста с целью регулирования процесса биоочистки сложных по составу сточных вод.

Одним из наиболее широко применяемых в аналитических целях ферментов является пероксидаза. Этот фермент используется в иммуноферментном анализе и при конструировании ферментных электродов. Высокочувствительные биосенсоры могут быть применены для анализа состава сточных вод, которые часто содержат сложные многокомпонентные смеси [131-133]. 
Для интегральной экспресс-оценки загрязнения окружающей среды предложен хемилюминометрический метод. Он основан на применении ферментативной тест-системы, в качестве которой использован комплексный полиферментный препарат из корня хрена, обладающий оксидазно-пероксидазной активностью в сочетании с сульфгидрильным реагентом и субстратом-флуорогеном [134, 135]. Метод показал свою состоятельность при картировании уровней загрязненности бассейна Невы и некоторых других водоемов Санкт-Петербурга.

\section{Заключение}

Высокая специфичность, экологическая безопасность ферментов делают их привлекательными реагентами для целлюлозно-бумажного производства. Ферментные технологии достаточно давно и успешно работают в ЦБП для интенсификации ряда основных технологических процессов. Использование ферментов позволяет создавать экологически привлекательные технологии. Ферменты эффективно используются для микробиологического контроля роста биопленок, интенсификации биологической очистки и переработки комплексных биологических осадков.

В настоящее время стоимость большинства ферментных препаратов высока, переработка значительных объемов образующихся сточных вод и осадков даже при небольших расходах ферментов требует существенных затрат. Развитие сферы производства ферментов, разработка новых эффективных препаратов комплексного действия на основе рекомбинантных клеточных культур в будущем позволят решить эту проблему и значительно увеличить вклад процессов биокатализа в совершенствование технологии и повышение экологической безопасности целлюлозно-бумажного производства.

\section{Список литературы}

1. Филиппович Ю. Б. Основы биохимии. 4-е изд. М., 1999. 512 с.

2. Синицын А.П., Черноглазов В.М., Гусаков А.В. Методы исследования и свойства целлюлолитических ферментов. М., 1990. Т. 25. С. 30-37.

3. Проскурина О.В., Короткова О.Г., Рожкова А.М., Матыс В.Ю., Кошелев А.В., Окунев О.Н., Немашкалов В.А., Синицына О.А., Синицын А.П. Применение технологии «фъюжн» для создания высокоэффективных биокатализаторов на основе рекомбинантных штаммов Penicillium verruculosum для конверсии целлюлозосодержащей биомассы // Катализ в промышленности. 2013. №5. С. 65-73.

4. Новожилов Е.В., Пошина Д.Н. Биотехнологии в производстве целлюлозы для химической переработки (Обзор) // Химия растительного сырья. 2011. №3. С. 15-32.

5. Aehle W. Enzymes in Industry. Weinheim: Wiley-VCH Verlag GmbH\&Co. KgaA, 2004. 484 p.

6. Новожилов Е.В. Применение ферментных технологий в целлюлозно-бумажной промышленности. Архангельск, 2013. 235 с.

7. Bajpai P. Biotechnology for Pulp and Paper Processing. Springer Science. 2012. 427 p.

8. Медведева С.А., Тимофеева С.А. Биотехнологии для повышения экологической безопасности целлюлознобумажной промышленности (Современное состояние) // Безопасность в техносфере. 2013. Т. 2, №3. С. 28-34.

9. Аксенов А.С., Новожилов Е.В., Демашев О.А., Опарина А.А. Промышленное использование ксиланаз при отбелке сульфатной целлюлозы // Целлюлоза. Бумага. Картон. 2006. Пилотный выпуск. С. 15-17.

10. Kantelinen A., Hortling B., Sundquist J. Proposed mechanism of the enzymatic bleaching of kraft pulps with xylanases // Holzforschung. 1993. Vol. 47. Pp. 18-28.

11. Biotechnology in Pulp and Paper Industry: volume editor: K-E. Ericsson, 1997. 340 p.

12. Bajpaj P. Application of enzymes in the pulp and paper industry // Biotechnol. Prog. 1999. N15. Pp. 147-157.

13. Valls C., Vidal T., Gallardo O. Obtaining low-HexA-content cellulose from eucalypt fibres: Which glycosil hydrolase family is more efficient? //Carbohydrate Polymers. 2010. Vol. 80, issue 1. Pp. 154-160.

14. Shatalov A., Pereira H. Impact of hexenuronic acids on xylanase-aided bio-bleaching of chemical pulps // Bioresource Technology. 2009. Vol. 100, issue 12. Pp. 3069-3075.

15. Аксенов А.С., Новожилов Е.В., Чухчин Д.Г. Деструкция лигноуглеводного комплекса сульфатной целлюлозы при ферментативной обработке ксиланазой // Физикохимия лигнина : материалы Междунар. конф. Архангельск, 2005. С. 89-93.

16. Комарова Г.В., Комаров В.И., Миловидова Л.А., Королева Т.А. Влияние предварительных перед отбелкой кислых обработок на изменение числа Каппа на удаление гексенуроновых кислот лиственной сульфатной целлюлозы // Международный молодежный экологический форум стран Баренцева региона. Архангельск. 2001. C. $184-185$.

17. Buchert J., Bergnor E., Lindblad G. Significance of xylan and glucomannan in the brightness reversion of kraft pulps // Tappi J. 1997. Vol. 80, N6. Pp. 165-170.

18. Wong K., Allison R., Spen S. Effects of alkali and oxygen extractions of kraft pulps on xylanase-aided bleaching // 2000 International Pulp Bleaching Conference: Oral presentations. TAPPI of Canada. Monreal, 2000. Pp. 63-67.

19. Nguyen D., Zhang X., Jiang Z.-H. Bleaching of kraft pulp by a commercial lipase: Accessory enzymes degrade hexenuronic acids // Enzyme Microbiol Technol. 2008. Vol. 43. Pp. 130-136. 
20. Noe P., Chevalier J., Mora F., Comtat J. Action of xylanases on chemical pulp fibres. Part II: Enzimatic beating // J. Wood Chem.Technol. 1986. Vol 6, N2. Pp. 167-184.

21. Mora F., Comtat J., Bamoud F. Action of xylanases on chemical pulp fibers. Part I: Investigations on cell-wall modifications // J. Wood Chem. Technol. 1986. Vol. 6. Pp. 147-165.

22. Bhardwaj N., Bajpai P., Bajpai P.K. Use of enzymes in modification of fibers for improved beatability // J. Biotechnology. 1996. Vol. 51. Pp. 21-26.

23. Gutierrez A. J.del Rio, Martinez M., Martinez A. The biotechnological control of pitch in paper pulp manufacturing // Trends in Biotechnology. 2001. Vol. 19, N9. Pp. 340-347

24. Back E., Allen L. Resin in suspensions and mechanisms of its deposition // Pitch Control, Wood Resin and Deresination. TAPPI Press. 2000. Pp. 151-183.

25. Mustranta A., Buchert J., Spetz P., Holmbom B. Treatment of mechanical pulp and process waters with lipase // Nordic Pulp Paper Res. J. 2001. Vol. 16, N2. Pp. 125-129.

26. Rundlof M., Eriksson M., Strom H., Wagberg L. Effect of mannanase and lipase on the properties of colloidal wood extractives and their interaction with mechanical pulp fines // Cellulose. 2002. Vol. 9. Pp. 127-137.

27. Qin M., Holmbom B. Effect of hydrophilic substances in spruce TMP resin on its physico-chemical characterization and deposition tendency // Colloids and Surfaces A: Physicochemical and Engineering Aspects. 2008. Vol. 312, issues 2-3. Pp. 226-230.

28. Kantelinen A., Jokinen O., Sarkki M-L. Effects on enzymes on the stability of colloidal pitch // 8th International Wood and Pulping Chemistry Conference Proceedings K.C.L. Helsinki. 1995. Vol. 1. 605 p

29. Xu F. Oxidation of phenols, anilines, and benzenethiols by fungal laccases: correlation between activity and redox potentials as well as halide inhibition // Biochemistry-US. 1996. Vol. 35. Pp. 7608-7614.

30. Bermek H., Li K., Eriksson K.- E. Pulp bleaching with marganese peroxidase and xylanase: synergistic effect // Tappi J. 2000. Vol. 83, N10. Pp. 1-11.

31. Paice M., Bourbonnais R., Reid I. Bleaching kraft pulps with oxidative enzymes and alkaline hydrogen peroxide // Tappi J. 1995. Vol. 78. Pp. 161-169.

32. Iimori I., Miyawaki S., Machida M. Biobleaching of unbleached and oxygen-bleached hardwood kraft pulp by culture filtrate containing manganese peroxidase and lignin peroxidase from Phanerochaete chrysosporium // Journal of Wood Science. 1998. Vol. 44. Pp. 451-456.

33. Moreira M., Sierra-Alvarez R., Lema J., Feijoo G., Field J. Oxidation of lignin in eucalyptus kraft pulp by manganese peroxidase from Bjerkandera sp. strain BOS55 // Bioresource Technology. 2001. Vol. 78, issue 1. Pp. 71-79.

34. Королева О.В., Федорова Т.В., Лукина Н.В., Тебенькова Д.Н., Воробьев Р.А. Использование биокаталитических процессов лигниноцеллюлозного действия для комплексной переработки отходов целлюлознобумажной промышленности. Фундаментальные и прикладные аспекты // Современные проблемы науки и образования. 2013. №5. [Электронный ресурс]. URL: www.science-education.ru/111-10229.

35. Pommier J-C., Goma G., Fuentes J-L., Rousset C., Jokinen O. Using enzymes to improve the product quality in the recycled paper industry Part II. Industrial applications // Tappi J. 1990. Vol. 73, N12. Pp. 197-200.

36. Jackson L., Heitmann J., Joyce T. Enzymatic modification of secondary fiber // Tappi J. 1993. Vol. 76, N3. Pp. 147-154.

37. Mansfield S., Swanson D., Roberts N. Enhancing Douglas-fir pulp properties with a combination of enzyme treatments and fiber fractionation // Tappi J. 1999. Vol. 82, N5. Pp. 152-158.

38. Дулькин Д.А., Спиридонов В.А., Комаров В.И. Современное состояние и перспективы использования вторичного волокна из макулатуры в мировой и отечественной индустрии бумаги. Архангельск, 2007. 1118 с.

39. Ow S. Biogical deinking methods of newsprint wastepaper // World pulp and paper technology. 1992. Pp. 63-66.

40. Viesturs U., Leite M., Eisimonte M. Biological deinking technology for the recycling of office waste papers // Bioresourse Technol. 1999. Vol. 67. Pp. 255-265.

41. Elegir G., Panizza E., Canetti M. Neutral enzyme assisted deinking of xerographic office waste with a cellulase/amylase mixture // Tappi J. 2000. Vol. 83, N11. Pp. 71-79.

42. Geng X., Li K. Deinking of recycled mixed office paper using two endo-glucanases, CelB and CelE, from the anaerobic fungus Orpinomyces PC-2 // Tappi J. 2003. Vol. 2, N7. Pp. 29-32.

43. Берлин А.Х., Тихоморов Д.В., Гутьеррес Б.Р. Оценка топоферментной активности целлюлаз и ксиланаз // Приклад. биохимия и микробиология. 1998. Т. 34, №4. С. 382-387.

44. Петерсен Х. Применение ферментов в технологии переработки макулатуры // Современные научные основы и инновационные технологии бумажно-картонных материалов с использованием вторичного волокна из макулатуры : тр. Междунар. науч.-техн. конф. Караваево, 2006. С. 31-34.

45. Prasad D.Y., Heitmann J., Joyce T. Enzymatic deinking of black and white letterpress printed newsprint waste // Progress in paper recycling. 1992. Vol. 1, N3. Pp. 21-30.

46. Новожилов Е.В., Кондаков А.В., Мартынов В.Ю., Крупенин И.С. Ферментативная обработка оборотных вод бумажных фабрик // Современные научные основы и инновационные технологии бумажно-картонных материалов с использованием вторичного волокна из макулатуры : науч. тр. 7-й Междунар. науч.-техн. конф. Караваево, 2010. С. 31-34.

47. Ricard M., Reid I. Purified pectinase lowers cationic demand in peroxide-bleached mechanical pulp // Enzyme and Microbial Technology. 2004. Vol. 34. Pp. 499-504.

48. Thornton J. Enzymatic degradation of polygalacturonic asids released from mechanical pulp during peroxide bleaching // Tappi J. 1994. Vol. 77, N3. Pp. 161-167.

49. Buchert J., Mustranta A., Holmbom B. Enzymatic control of dissolved and colloidal substances during mechanical pulping // Biotechnology in Pulp and Paper Industry. $8^{\text {th }}$ ICBPPI / Ed. L. Viikari, R. Lantto. 2002. Pp. 271-280.

50. Reid I., Ricarg M. Decreasing cationic demand and increasing fines and filler retention of peroxide-bleached thermomechanical pulp with pectinase enzyme // Paprican. 1998. P. 20.

51. Reid I., Ricarg M. Pectinase in papermaking: solving retention problems in mechanical pulp bleached with hydrogen peroxide // Enzyme and Microbial Technology. 2000. Vol. 26, N2-4. Pp. 115-123. 
52. Овсянникова Е.А., Дулькин Д.А., Новожилов Е.В., Смирнов Е.В., Тышкунова И.В. О микробиологической деструкции крахмала в технологических средах бумажной фабрики // Биотехнологии в химико-лесном комплексе : матер. Междун. науч. конф. Архангельск, 2014. С. 243-247.

53. Antonopoulos V., Rob A., Ball A. Dechlorination of chlorophenols using extracellular peroxidases produced by Streptomyces albus ATCC 3005 // Enzyme and Microbial Technology. 2001. Vol. 29. Pp. 62-69.

54. Лапин В.В., Смоляков А.И., Кудрина Н.Д. Загрязнения в бумажной массе из $100 \%$ макулатуры: влияние на степень помола и прочность бумаги и картона // Целлюлоза. Бумага. Картон. 2001. № 7-8. С. 32-34.

55. Идиатуллин А.М., Полканова Н.Л., Сотников А.А., Хорошилов Н.В. О применении катионного крахмала в производстве бумаги и картона из вторичного волокна // Теория и технология бумажно-картонной продукции из вторичного волокна : науч. тр. 5-й Междунар. науч.-техн. конф. Караваево, 2004. С. 58-62.

56. Сотников А.А., Саможенков В.М., Сотникова А.Т. Применение химических добавок при производстве бумаги и картона на Майкопском ЗАО «Картонтара» // Теория и технология бумажно-картонной продукции из вторичного волокна : науч. тр. 5-й Междунар. науч.-техн. конф. Караваево, 2004. С. 43-46.

57. Идиатуллин А.М., Тараканова Н.А., Идиатуллина И.С., Любавина И.В. О бумагообразующих свойствах разных видах вторичного волокна // Проблемы механики целлюлозно-бумажных материалов : матер. II Междунар. науч.-техн. конф. Архангельск, 2013. С. 33-43.

58. Новожилов Е.В., Хадыко И.А., Смирнов Е.В., Тышкунова И.В., Лукина В.А. Определение растворенного крахмала в технологических средах различными методами // Биотехнологии в химико-лесном комплексе : матер. Междун. науч. конф. Архангельск, 2014. С. 235-238.

59. Paper, board and process waters. Starch content. SCAN-P 91:09. SCAN-W 13:09 Accepted 2008.

60. Bajpaj P. Solving the problems of recycled fiber processing with enzymes // BioResources. 2010. Vol. 5, N2. Pp. 1-15.

61. Jones D. Enzymes: Using mother natures tools to control man-made stickies // Pulp and Paper Canada. 2005. Vol. 106, N2. Pp. 23-25.

62. Rice L.E., Kehoe V.M., Robertson L.R. The diversity of filamentous bacteria in paper systems from incoming water to wastewater effluent // Tappi International Environmental Conference. Denver, 2000. Pp. 559-565.

63. Kiuru J., Tsitko I., Sievanen J., Wathen R. Optimization of biocide strategies for fine paper machines // Bioresources. 2010. N5 (2). Pp. 514-524.

64. Kiuru J., Tukiainen P., Tsitko I.Electrochemically generated biocides for controlling contamination in papermaking // Bioresources. 2010. N5 (4). Pp. 2664-2680.

65. Torres C.E., Lenon G., Craperi D., Wilting R., Blanco Á. Enzymatic treatment for preventing biofilm formation in the paper industry // Appl. Microbiol. Biotechnol. 2011. N92. Pp. 95-103.

66. Torres C. E., Negro C., Fuente E., Blanco A. Enzymatic approaches in paper industry for pulp refining and biofilm control // Appl Microbiol Biotechnol. 2012. N96. Pp. 327-344.

67. Patent 5071765 (USA). Application of multiple enzyme blend to control industrial slime of equipment surfaces $/$ C.L. Wiatr. 10.12.1991.

68. Patent 4055467 (USA). Enzymatic dispersion of biological slimes / R.J. Christensen, G.J. Zivtins. 25.10.1977

69. Высокостабильная пуллуланаза, выделенная из Thermus Acuaticus // Микробиологическая промышленность за рубежом: Экспресс-информация. ЦБНТИ Минмедбиопром СССР, 1987. №7. С. 13-14.

70. Chaudhary A., Gupta L., Gupta J., Banerjee U. Levanases for control of slime in paper manufacture // Biotechnology Advances. 1998. Vol. 16, N5-6. Pp. 899-912.

71. Patent 4684469 (USA). Two component biocidal process / D.E. Pedersen, H.J. Hatcher. 04.08.1987.

72. Patent 3773623 (USA). Slime control in industrial waters / H.J. Hatcher, R.J. Truda, T.G. Lechner, C.R. McDuff. 20.11.1973.

73. Кретович В.Л., Метлицкий Л.В., Бокучава М.А., Скобелева Н.И., Кишковский 3.Н., Ильин Г.С., Фениксова Р.В. Техническая биохимия. М., 1973. 456 с.

74. Получение протопласта и внутриклеточного фермента при деградации клеточной стенки ряда грибов // Микробиологическая промышленность за рубежом: Экспресс-информация. ЦБНТИ Минмедбиопром СССР, 1987. №7. C. 20-21.

75. Личутина Т.Ф., Мискевич И.В., Бровко О.С., Гусакова М.А. Оптимизация нормирования сброса стоков предприятий ЦБП в водотоки. Екатеринбург, 2005. 211 с.

76. Косарева Е.Н. Снижение токсичности и остаточной загрязненности сточных вод целлюлозно-бумажных предприятий при различных вариантах биологической очистки : дис. ... канд. техн. наук. Архангельск, 2007. 145 с.

77. Жмур Н.С. Технологические и биохимические процессы очистки сточных вод на сооружениях с аэротенками. M., 2003. $512 \mathrm{c}$

78. Яковлев С.В., Воронов Ю.В. Биологические фильтры. 2-е изд., перераб. и доп. М., 1982. 120 с.

79. Гюнтер Н.И., Казаровец Н.М. Методика контроля за дегидрогеназной активностью при технологическом контроле за работой аэротенков. М., 1970.

80. Gabbitas K., Huang J. Dehydrogenases activity of activated sludge // Toxicological and Environmental Chemistry. 1984. Vol. 8. Pp. 151-164.

81. Патент 2476598 (РФ). Способ количественного определения дегидрогеназной активности / Д.Г. Чухчин, П.А. Тупин. 2013.

82. Чухчин Д.Г., Тупин П.А., Новожилов Е.В., Соколов О.М. Разработка нового метода оценки ферментативной окислительной способности // Известия вузов. Лесной журнал. 2010. №3. С. 119-124.

83. Патент на полезную модель 117149 (РФ). Устройство для количественного определения скорости / Д.Г. Чухчин, П.А. Тупин. 2011.

84. Ricotta A. Unz R., Bollag J. Role of a Laccase in the Degradation of Pentachlorophenol // Bulletin of Environmental Contamination and Toxicology. 1996. Vol. 57. Pp. 560-567. 
85. Guerra A., Ferraz A., Cotrim A. Polymerization of lignin fragments contained in a model effluent by lyphenoloxidases and horseradish peroxidase/hydrogen peroxide system // Enzyme and Microbial Technology. 2000. Vol. 26. Pp. 315-323.

86. Mishra M., Thakur I.S. Isolation and characterization of alkalotolerant bacteria and optimization of process parameters for decolorization and detoxification of pulp and paper mill effluent by Taguchi approach // Biodegradation. 2010. N21. Pp. 967-978.

87. Mishra M., Thakur I.S. Purification, characterization and mass spectroscopic analysis of thermo-alkalotolerant b-1,4 endoxylanase from Bacillus sp. and its potential for dye decolorization // International Biodeterioration \& Biodegradation. 2011. N65. Pp. 301-308.

88. Sahoo D.K., Gupta R. Evaluation of ligninolytic microorganisms for efficient decolorization of a small pulp and paper mill effluent // Process Biochemistry. 2005. N40. Pp. 1573-1578.

89. Selvam K., Swaminathan K., Rasappan K., Rajendran R., Pattabhi S. Decolourization and dechlorination of a pulp and paper industry effluent by Thelephora sp // Ecol Environ Conserv. 2006. Vol. 12. Pp. 223-226.

90. Dec J., Bollag J.-M. Detoxification of substituted phenols by oxidoreductive enzymes through polymerization reactions // Archives of Environmental Contamination Toxicology. 1990. Vol. 19. Pp. 543-550.

91. Lankinen V.P., Inkeröinen M.M., Pellinen J., Hatakka A.I. The Onset of Lignin-Modifying Enzymes, Decrease of AOX and Color Removal by White-Rot Fungi Grown on Bleach Plant Effluents // Water Science and Technology. 1991. Vol 24, N3-4. Pp. 189-198.

92. Manzanares P.I, Fajardo S., Martin C. Production of lignolytic activities when treating paper pulp effluents by Trametes versicolor // Journal of Biotechnology. 1995. Vol. 43, N2. Pp. 125-132.

93. Monje P., González-García S., Moldes D. Biodegradability of kraft mill TCF biobleaching effluents: Application of enzymatic laccase-mediator system // Water research. 2010. Vol. 44, issue 7. Pp. 2211-2220.

94. Widsten P., Kandelbauer A. Laccase application in the forest products industry: a review // Enzyme and microbial technology. 2008. Vol. 42. Pp. 293-307.

95. Milstein O., Haars A., Majcherczyk A. Removal of Chlorophenols and Chlorolignins from Bleaching Effluent by Combined Chemical and Biological Treatment // Water Science Technology. 1988. Vol. 20, N1. Pp. 161-170.

96. Szklarz G., Leonowicz A. Cooperation between fungal laccase and glucose oxidase in the degradation of lignin derivatives // Phytochemistry. 1986. Vol. 25. Pp. 2530-2539.

97. Patent 6733673 (USA). Method of dewatering sludge using enzymes / J. Sarkar, J. Shah, M. Ramesh. 11.05.2004.

98. Mehna A., Bajpai P., Bajpai P. Studies on decolorization of effluent from a small pulp mill utilizing agriresidues with Trametes versicolor // Enzyme Microbial Technol. 1995. N17. Pp. 18-22.

99. Zhang X., Stebbing D.W., Soong G., Saddler J.N., Beatson R.P. A combined fungal and enzyme treatment system to remove TMP/newsprint mill white water substances // Tappi Journal. 2002. May. Pp. 26-32.

100. Demarche P., Junghanns C., Nair R.R., Agathos S.N. Harnessing the power of enzymes for environmental stewardship // Biotechnology Advances. 2012. N30. Pp. 933-953.

101. Карпухин В.Ф., Файнгольд З.Л., Белов Ю.Б. Обработка осадков сточных вод: обзор. М., 1974. 64 с.

102. Евилевич А.З., Евилевич М.А. Утилизация осадков сточных вод. Л., 1988. 248 с.

103. Неволин В.Ф., Коровин Л.К. Экологическая оценка состояния и перспектив развития ЦБП России // Целлюлоза. Бумага. Картон. 1995. №7. С. 29-32.

104. Дулькин Д.А. Утилизация осадков и макулатуры, не используемой в бумажном производстве // Целлюлоза. Бумага. Картон. 2009. №6. С. 50-55.

105. Евилевич М.А. Утилизация активного ила предприятий целлюлозно-бумажной промышленности. Обзор. М., 1977. $47 \mathrm{c}$

106. Новое в прикладной энзимологии // Микробиологическая промышленность за рубежом: Экспрессинформация. ЦБНТИ Минмедбиопром СССР. 1987. №3. С. 20-21.

107. Бильдер 3.П., Калишевич Ю.И. Современные способы очистки сточных вод. Обзор. М., 1978. 59 с.

108. Туровский И.С. Обработка осадков сточных вод. 2-е изд., перераб. и доп. М., 1982. 223 с.

109. Романов Г.А., Семенов В.П. Механическая очистка сточных вод целлюлозно-бумажных предприятий. М., 1985. $112 \mathrm{c}$.

110. Болотова К.С., Новожилов Е.В., Соколов О.М. Обезвоживание осадка сточных вод ЦБП с применением ферментных препаратов // Охрана окружающей среды и рациональное использование природных ресурсов : сб. науч. тр. Вып. 73. Архангельск, 2007. С. 21-26.

111. Bonilla S., Tran H., Grant D. Allen Enhancing pulp and paper mill biosludge dewaterability using enzymes // Water research. 2015. N68. Pp. 692-700.

112. Макаренко А.А., Гаркуша И.Н., Корчак Г.И. Санитарно-экологические проблемы сбора и переработки макулатуры // Целлюлоза. Бумага. Картон. 2004. №7. С. 64-66.

113. Тарасюк В.Т. Актуальность и перспективы применения биополимеров в пищевой промышленности // Консервная промышленность сегодня: технологии, маркетинг, финансы. 2011. №3. С. 55-62.

114. Lund L.R., Lyford K., South C.R., Walsum P.V., Levenson K. Evaluation of paper sludges for amenability to enzymatic hydrolysis and conversion to ethanol // Tappi Journal. 2007. Febr. P. 50.

115. Marques S., Alves L., Roseiro J.C., Girio F.M. Conversion of recycled paper sludge to ethanol by SHF and SSF using Pichia stipites // Biomass and bioenergy. 2008. N32. Pp. 400-406.

116. Prasetyo J., Kato T., Park E.Y. Efficient cellulase-catalyzed saccharification of untreated paper sludge targeting for biorefinery // Biomass and bioenergy. 2010. N34. Pp. 1906-1913.

117. Prasetyo J., Park E.Y. Waste paper sludge as a potential biomass for bio-ethanol production // Korean J. Chem. Eng. 2013. N30 (2). Pp. 253-261.

118. Болотова К.С. Совершенствование подготовки осадков сточных вод целлюлозно-бумажного производства к сжиганию : дис. ... канд. техн. наук. Архангельск, 2009. 118 с. 
119. Ларченко В.В. Микробно-ферментная конверсия и деодоризация отходов сточных вод // Экология производства. 2006. №4. С. 42-45.

120. Рабинович М.Л., Мельник М.С. Прогресс в изучении целлюлолитических ферментов и механизм биодеградации высокоупорядоченных форм целлюлозы // Успехи биологической химии. 2000. Т. 40. С. 205-266.

121. Балов А., Ашпина О. Мировой рынок биополимеров // The Chemical Journal. 2012. Март. С. 48-53.

122. Vikman M., Itavaara M, Poutanen K. Measurement of the Biodegradation of Starch-Based Materials by Enzymatic Methods and Composting // J. of Environmental Polymer Degradation. 1995. Vol. 3, N1. Pp. 23-29.

123. Itavaara M., Siika-aho M., Viikari L. Enzymatic Degradation of Cellulose-Based Materials // J. of Environmental Polymer Degradation. 1999. Vol. 7, N2. Pp. 67-73.

124. Хадыко И.А., Чухчин Д.Г., Новожилов Е.В. Применение ферментов для оценки биоразлагаемости целлюлозосодержащих материалов // Биотехнологии в химико-лесном комплексе : матер. Межд. науч. конфер. Архангельск, 2014. С. 310-313.

125. Хадыко И.А., Казаков Я.В., Новожилов Е.В., Канарский А.В. Применение ферментов для оценки биодеградации материалов экспресс-методом // Вестник Казанского технологического университета. 2014. Т. 17 , №13. C. $277-280$.

126. Козлова А.А., Варакин Е.А., Чухчин Д.Г. Изучение влияния седиментационных свойств активного ила на дегидрогеназную активность // Биотехнологии в химико-лесном комплексе : матер. Межд. науч. конфер. Архангельск, 2014. С. 178-180.

127. Варакин Е.А., Халина Е.В., Рудакова В.А., Чухчин Д.Г., Новожилов Е.В. Определение дегидрогеназной активности микроорганизмов активного ила в процессе биологической очистки сточных вод // Биотехнологии в химико-лесном комплексе : матер. Межд. науч. конфер. Архангельск, 2014. С. 99-103.

128. Чухчин Д.Г., Чуркина Ю.В., Рудакова В.А., Варакин Е.А., Халина Е.В., Новожилов Е.В. Определение окислительной способности микроорганизмов биопленки активного ила очистных сооружений // Биотехнологии в химико-лесном комплексе : матер. Межд. науч. конфер. Архангельск, 2014. С. 329-333.

129. Рудакова В.А., Филиппов И.Б., Чухчин Д.Г. Микробиологический контроль на сооружениях биологической очистки ОАО «Архангельский ЦБК» // Биотехнологии в химико-лесном комплексе : матер. Межд. науч. конфер. Архангельск, 2014. С. 264-267.

130. Закиров Р.К, Ахмадуллина Ф.Ю., Вербенко И.В., Сироткин А.С. Ферментативная диагностика промышленных илов в процессах продленной аэрации сточных вод // Вестник Казанского технологического университета. 2009. №2. С. 33-40.

131. Айзенштадт М.А., Боголицын К.Г. Пероксидазное окисление лигнина и его модельных соединений // Химия растительного сырья. 2009. №2. С. 5-18.

132. Алпеева И.С. Анионные пероксидазы и их применение в биоанализе : автореф. дис. ... канд. хим. наук. М., 2007. $28 \mathrm{c}$.

133. Alpeeva I.S., Niculescu-Nistor M., Castillo Leon J., Csoregi E., Sakharov I.Yu. Palm tree peroxidase-based biosensor with unique characteristics for hydrogen peroxide and glucose monitoring // Proc. 18 Intern. Symp. On Bioelectrochemistry and Bioenergetics. 14-19 June 2005. Coimbra. Portugal. P. 123.

134. Калацкий Ю.М., Петрова Т.А., Стефанов В.Е. Ферментативный экспресс-тест для интегральной оценки загрязнения окружающей среды и опыт его применения // Экология и промышленность России. 2012. №12. С. 17-21.

135. Патент 2359036 (РФ). Способ интегральной экспресс-оценки загрязнения окружающей среды / В.Ю. Васильев, Ю.М. Калацкий, В.Е. Стефанов, Т.А. Петрова. 2009. 
Bolotova K.S. , Novozhilov E.V. ENZYMES APPLICATION FOR IMPROVING ECOLOGICAL SAFETY OF PULP AND PAPER INDUSTRY

M.V. Lomonosov Northern (Arctic) Federal University, Severnaya Dvina Emb. 17, Arkhangelsk, 163002 (Russia), e-mail: biotech@narfu.ru

Review concerning enzymatic technologies for pulp and paper industry is presented in the article. Enzymes as additives for technological process provide selective destruction of different components and have positive effect on compositions of technological fluids, improving ecological safety of the factory.

Enzymatic treatment (xylanases, cellulases, laccases, peroxydases) enhances lignin removing and decreases delignificating and bleaching agents dosage including chlorine-bleaching agents. Pitch removal with enzymes (lipases, laccases) provides destruction of pitch components. As a result removing of extractives destruction products and their bioconversion are more effective. Enzymatic deinking is alternative for chemical processes based on alkali, hydrogen peroxide, sodium silicate or chelates additives. Cellulases, xylanases, cellulases are recommended for these purposes.

Microbiological monitoring of technological fluids and prevention of biofilms formation are perspective directions for industrial enzymes application. Enzymatic destruction provides obtaining low-molecular products and increasing bioconversion thereof.

Based on the complex approach for technology realization (water recycling, quality of waste water treatment) enzymes are recommended for pollutants degradation and decreasing of waste water colour in the technological fluids. Enzyme preparations for waste water sludge utilization as a biofuel, compost and fertilizers are developed as well.

Enzymatic analytic methods (peroxydase) provide highly-sensitive and selective detection of different substances in technological fluids.

Keywords: enzyme, pulp and paper industry, ecology, microbiological monitoring, biological treatment, wastewater sludge, analytic methods.

\section{References}

1. Filippovich Iu. B. Osnovy biokhimii. [Fundamentals of Biochemistry]. 4 ed. Moscow, 1999, 512 p. (in Russ.).

2. Sinitsyn A.P., Chernoglazov V.M., Gusakov A.V. Metody issledovaniia $i$ svoistva tselliuloliticheskikh fermentov. [Research methods and properties of cellulolytic enzymes]. Moscow, 1990, vol. 25, pp. 30-37. (in Russ.).

3. Proskurina O.V., Korotkova O.G., Rozhkova A.M., Matys V.Iu., Koshelev A.V., Okunev O.N., Nemashkalov V.A., Sinitsyna O.A., Sinitsyn A.P. Kataliz v promyshlennosti, 2013, no. 5, pp. 65-73. (in Russ.).

4. Novozhilov E.V., Poshina D.N. Khimiia rastitel'nogo syr'ia, 2011, no. 3, pp. 15-32. (in Russ.).

5. Aehle W. Enzymes in Industry. Weinheim: Wiley-VCH Verlag GmbH\&Co. KgaA, 2004. 484 p.

6. Novozhilov E.V. Primenenie fermentnykh tekhnologii $v$ tselliulozno-bumazhnoi promyshlennosti. [The use of enzyme technology in the pulp and paper industry]. Arkhangelsk, 2013, 235 p. (in Russ.).

7. Bajpai P. Biotechnology for Pulp and Paper Processing. Springer Science. 2012. 427 p.

8. Medvedeva S.A., Timofeeva S.A. Bezopasnost'v tekhnosfere, 2013, vol. 2, no. 3, pp. 28-34. (in Russ.).

9. Aksenov A.S., Novozhilov E.V., Demashev O.A., Oparina A.A. Tselliuloza. Bumaga. Karton, 2006, pp. 15-17. (in Russ.).

10. Kantelinen A., Hortling B., Sundquist J. Holzforschung, 1993, vol. 47, pp. 18-28.

11. Biotechnology in Pulp and Paper Industry: volume editor: K-E. Ericsson, 1997. 340 p.

12. Bajpaj P. Biotechnol. Prog., 1999, no. 15, pp. 147-157.

13. Valls C., Vidal T., Gallardo O. Carbohydrate Polymers, 2010, vol. 80, issue 1, pp. 154-160.

14. Shatalov A., Pereira H. Bioresource Technology, 2009, vol. 100, issue 12, pp. 3069-3075.

15. Aksenov A.S., Novozhilov E.V., Chukhchin D.G. Fizikokhimiia lignina: materialy mezhdunar. konf. [Physical chemistry of lignin: Proceedings of the International Conference]. Arkhangelsk, 2005, pp. 89-93. (in Russ.).

16. Komarova G.V., Komarov V.I., Milovidova L.A., Koroleva T.A. Mezhdunarodnyi molodezhnyi ekologicheskii forum stran Barentseva regiona. [International Youth Environmental Forum of the Barents region]. Arkhangelsk, 2001, pp. 184-185. (in Russ.).

17. Buchert J., Bergnor E., Lindblad G. Tappi J., 1997, vol. 80, no. 6, pp. 165-170.

18. Wong K., Allison R., Spen S. 2000 International Pulp Bleaching Conference: Oral presentations, TAPPI of Canada, Monreal, 2000, pp. 63-67.

19. Nguyen D., Zhang X., Jiang Z.-H. Enzyme Microbiol Technol, 2008, vol. 43, pp. 130-136.

20. Noe P., Chevalier J., Mora F., Comtat J. J. Wood Chem.Technol., 1986, vol. 6, no. 2, pp. 167-184.

21. Mora F., Comtat J., Bamoud F. J. Wood Chem. Technol., 1986, vol. 6, pp. 147-165.

22. Bhardwaj N., Bajpai P., Bajpai P.K. J. Biotechnology., 1996, vol. 51, pp. 21-26.

23. Gutierrez A. J.del Rio, Martinez M., Martinez A. Trends in Biotechnology, 2001, vol. 19, no. 9, pp. 340-347.

24. Back E., Allen L. Pitch Control, Wood Resin and Deresination. TAPPI Press, 2000, pp. 151-183.

25. Mustranta A., Buchert J., Spetz P., Holmbom B. Nordic Pulp Paper Res. J., 2001, vol. 16, no. 2, pp. 125-129.

26. Rundlof M., Eriksson M., Strom H., Wagberg L. Cellulose, 2002, vol. 9, pp. 127-137.

27. Qin M., Holmbom B. Colloids and Surfaces A: Physicochemical and Engineering Aspects, 2008, vol. 312, issues 2-3, pp. 226-230.

28. Kantelinen A., Jokinen O., Sarkki M-L. 8th International Wood and Pulping Chemistry Conference Proceedings K.C.L. Helsinki, 1995, vol. 1. 605 p.

29. Xu F. Biochemistry-US, 1996, vol. 35, pp. 7608-7614.

30. Bermek H., Li K., Eriksson K.- E. Tappi J., 2000, vol. 83, no. 10, pp. 1-11.

31. Paice M., Bourbonnais R., Reid I. Tappi J., 1995, vol. 78, pp. 161-169.

32. Iimori I., Miyawaki S., Machida M. Journal of Wood Science, 1998, vol. 44, pp. 451-456.

33. Moreira M., Sierra-Alvarez R., Lema J., Feijoo G., Field J. Bioresource Technology, 2001, vol. 78, issue 1, pp. 71-79.

\footnotetext{
* Corresponding author.
} 
34. Koroleva O.V., Fedorova T.V., Lukina N.V., Teben'kova D.N., Vorob'ev R.A. Sovremennye problemy nauki $i$ obrazovaniia, 2013, no. 5. URL: www.science-education.ru/111-10229. (in Russ.).

35. Pommier J-C., Goma G., Fuentes J-L., Rousset C., Jokinen O. Tappi J., 1990, vol. 73, no. 12, pp. 197-200.

36. Jackson L., Heitmann J., Joyce T. Tappi J., 1993, vol. 76, no. 3, pp. 147-154.

37. Mansfield S., Swanson D., Roberts N. Tappi J., 1999, vol. 82, no. 5, pp. 152-158.

38. Dul'kin D.A., Spiridonov V.A., Komarov V.I. Sovremennoe sostoianie i perspektivy ispol'zovaniia vtorichnogo volokna iz makulatury $v$ mirovoi i otechestvennoi industrii bumagi. [Current status and prospects of using recycled fiber from waste paper in the global and domestic industry paper]. Arkhangelsk, 2007, 1118 p. (in Russ.).

39. Ow S. World pulp and paper technology, 1992, pp. 63-66.

40. Viesturs U., Leite M., Eisimonte M. Bioresourse Technol., 1999, vol. 67, pp. 255-265.

41. Elegir G., Panizza E., Canetti M. Tappi J., 2000, vol. 83, no. 11, pp. 1-9.

42. Geng X., Li K. Tappi J., 2003, vol. 2, no. 7, pp. 29-32.

43. Berlin A.Kh., Tikhomorov D.V., Gut'erres B.R. Priklad. biokhimiia i mikrobiologiia, 1998, vol. 34, no. 4, pp. $382-387$. (in Russ.).

44. Petersen Kh. Sovremennye nauchnye osnovy i innovatsionnye tekhnologii bumazhno-kartonnykh materialov $s$ ispol'zovaniem vtorichnogo volokna iz makulatury: nauch. tr. mezhdunar. nauch.-tekhn. konf. [Modern scientific basis and innovative technology of paper and cardboard materials using recycled fiber from waste paper: scientific papers International Scientific Conference]. Karavaevo, 2006, pp. 31-34. (in Russ.).

45. Prasad D.Y., Heitmann J., Joyce T. Progress in paper recycling, 1992, vol. 1, no. 3, pp. 21-30.

46. Novozhilov E.V., Kondakov A.V., Martynov V.Iu., Krupenin I.S. Sovremennye nauchnye osnovy i innovatsi-onnye tekhnologii bumazhno-kartonnykh materialov s ispol'zovaniem vtorichnogo volokna iz makulatury: nauch. tr. 7-i Mezhdunar. nauch.-tekhn. konf. [Modern scientific basis and innovative technology of paper and cardboard materials using recycled fiber from waste paper: scientific works of the 7th International Scientific and Technical Conference]. Karavaevo, 2010, pp. 31-34. (in Russ.).

47. Ricard M., Reid I. Enzyme and Microbial Technology, 2004, vol. 34, pp. 499-504.

48. Thornton J. Tappi J., 1994, vol. 77, no. 3, pp. 161-167.

49. Buchert J., Mustranta A., Holmbom B. Biotechnology in Pulp and Paper Industry. $8^{\text {th }}$ ICBPPI. Editors: L. Viikari, R. Lantto. 2002, pp. 271-280.

50. Reid I., Ricarg M. Paprican, 1998, p. 20.

51. Reid I., Ricarg M. Enzyme and Microbial Technology, 2000, vol. 26, no. 2-4, pp. 115-123.

52. Ovsiannikova E.A., Dul'kin D.A., Novozhilov E.V., Smirnov E.V., Tyshkunova I.V. Biotekhnologii v khimiko-lesnom komplekse: Materialy mezhdunarodnoi nauchnoi konferentsii. [Biotechnology in the Chemical-forest complex: Proceedings of the international scientific conference]. Arkhangelsk, 2014, pp. 243-247. (in Russ.).

53. Antonopoulos V., Rob A., Ball A. Enzyme and Microbial Technology, 2001, vol. 29, pp. 62-69.

54. Lapin V.V., Smoliakov A.I., Kudrina N.D. Tselliuloza. Bumaga. Karton, 2001, no. 7-8, pp. 32-34. (in Russ.).

55. Idiatullin A.M., Polkanova N.L., Sotnikov A.A., Khoroshilov N.V. Sovremennye nauchnye osnovy i innovatsi-onnye tekhnologii bumazhno-kartonnykh materialov s ispol'zovaniem vtorichnogo volokna iz makulatury: nauch. tr. 5-i Mezhdunar. nauch.-tekhn. konf. [Modern scientific basis and innovative technology of paper and cardboard materials using recycled fiber from waste paper: scientific works of the 5th International Scientific and Technical Conference]. Karavaevo, 2004, pp. 58-62. (in Russ.).

56. Sotnikov A.A., Samozhenkov V.M., Sotnikova A.T. Sovremennye nauchnye osnovy i innovatsi-onnye tekhnologii bumazhno-kartonnykh materialov s ispol'zovaniem vtorichnogo volokna iz makulatury: nauch. tr. 5-i Mezhdunar. nauch.-tekhn. konf. [Modern scientific basis and innovative technology of paper and cardboard materials using recycled fiber from waste paper: scientific works of the 5th International Scientific and Technical Conference]. Karavaevo, 2004, pp. 43-46. (in Russ.).

57. Idiatullin A.M., Tarakanova N.A., Idiatullina I.S., Liubavina I.V. Problemy mekhaniki tselliulozno-bumazhnykh materialov: mater. II mezhdunar. nauch.-tekhn. konf. [Problems of pulp and paper materials : Materials of the II International Scientific and Technical Conference]. Arkhangelsk, 2013, pp. 33-43. (in Russ.).

58. Novozhilov E.V., Khadyko I.A., Smirnov E.V., Tyshkunova I.V., Lukina V.A. Biotekhnologii v khimiko-lesnom komplekse: materialy mezhdunarodnoi nauchnoi konferentsii. [Biotechnology in the Chemical-forest complex: Proceedings of the International Conference]. Arkhangelsk, 2014, pp. 235-238. (in Russ.).

59. Paper, board and process waters. Starch content. SCAN-P 91:09. SCAN-W 13:09 Accepted 2008.

60. Bajpaj P. BioResources, 2010, vol. 5, no. 2, pp. 1-15.

61. Jones D. Pulp and Paper Canada, 2005, vol. 106, no. 2, pp. 23-25.

62. Rice L.E., Kehoe V.M., Robertson L.R. Tappi International Environmental Conference. Denver, 2000. Pp. 559-565.

63. Kiuru J., Tsitko I., Sievanen J., Wathen R. Bioresources, 2010, no. 5 (2), pp. 514-524.

64. Kiuru J., Tukiainen P., Tsitko I. Bioresources, 2010, no. 5 (4), pp. 2664-2680.

65. Torres C.E., Lenon G., Craperi D., Wilting R., Blanco Á. Appl. Microbiol. Biotechnol., 2011, no. 92, pp. 95-103.

66. Torres C. E., Negro C., Fuente E., Blanco A. Appl. Microbiol. Biotechnol., 2012, no. 96, pp. 327-344.

67. Patent 5071765 (USA). 10.12.1991.

68. Patent 4055467 (USA). 25.10.1977.

69. Mikrobiologicheskaia promyshlennost' za rubezhom: Ekspress-informatsiia. [Microbiological industry abroad: Express information], 1987, no. 7, pp. 13-14. (in Russ.).

70. Chaudhary A., Gupta L., Gupta J., Banerjee U. Biotechnology Advances, 1998, vol. 16, no. 5-6, pp. 899-912.

71. Patent 4684469 (USA). 04.08.1987.

72. Patent 3773623 (USA). 20.11.1973.

73. Kretovich V.L., Metlitskii L.V., Bokuchava M.A., Skobeleva N.I., Kishkovskii Z.N., Il'in G.S., Feniksova R.V. Tekhnicheskaia biokhimiia. [Technical Biochemistry]. Moscow, 1973, 456 p. (in Russ.). 
74. Mikrobiologicheskaia promyshlennost' za rubezhom: Ekspress-informatsiia. [Microbiological industry abroad: Express information], 1987, no. 7, pp. 20-21. (in Russ.).

75. Lichutina T.F., Miskevich I.V., Brovko O.S., Gusakova M.A. Optimizatsiia normirovaniia sbrosa stokov predpriiatii $T s B P v$ vodotoki. [Optimization of rationing discharge of sewage into waterways pulp and paper enterprises]. Ekaterinburg, 2005, 211 p. (in Russ.).

76. Kosareva E.N. Snizhenie toksichnosti i ostatochnoi zagriaznennosti stochnykh vod tselliulozno-bumazhnykh predpriiatii pri razlichnykh variantakh biologicheskoi ochistki: dis. ... kand. tekhn. nauk. [Reduced toxicity and residual contamination of waste water Pulp and paper mills in different types of biological treatment: the dissertation of the candidate of technical sciences]. Arkhangelsk, 2007, 145 p. (in Russ.).

77. Zhmur N.S. Tekhnologicheskie i biokhimicheskie protsessy ochistki stochnykh vod na sooruzheniiakh s aerotenkami. [Technological and biochemical processes of wastewater treatment plants with the aeration tanks]. Moscow, 2003, 512 p. (in Russ.).

78. Iakovlev S.V., Voronov Iu.V. Biologicheskie fil'try. [Biological filters]. Moscow, 1982, 120 p. (in Russ.).

79. Giunter N.I., Kazarovets N.M. Metodika kontrolia za degidrogenaznoi aktivnost'iu pri tekhnologicheskom kontrole za rabotoi aerotenkov. [Methods of control of dehydrogenase activity in the technological monitoring of the aeration tank]. Moscow, 1970. (in Russ.).

80. Gabbitas K., Huang J. Toxicological and Environmental Chemistry, 1984, vol. 8, pp. 151-164.

81. Patent 2476598 (RU). 2013. (in Russ.).

82. Chukhchin D.G., Tupin E.V. Novozhilov Sokolov O.M. Izvestiia vuzov. Lesnoi zhurnal, 2010, no. 3, pp. $119-124$. (in Russ.).

83. A utility model 117149 (RU). 2011. (in Russ.).

84. Ricotta A. Unz R., Bollag J. Bulletin of Environmental Contamination and Toxicology, 1996, vol. 57, pp. $560-567$.

85. Guerra A., Ferraz A., Cotrim A. Enzyme and Microbial Technology, 2000, vol. 26, pp. 315-323.

86. Mishra M., Thakur I.S. Biodegradation, 2010, no. 21, pp. 967-978.

87. Mishra M., Thakur I.S. International Biodeterioration \& Biodegradation, 2011, no. 65, pp. 301-308.

88. Sahoo D.K., Gupta R. Process Biochemistry, 2005, no. 40, pp. 1573-1578.

89. Selvam K., Swaminathan K., Rasappan K., Rajendran R., Pattabhi S. Ecol Environ Conserv., 2006, vol. 12, pp. $223-226$.

90. Dec J., Bollag J.-M. Archives of Environmental Contamination Toxicology, 1990, vol. 19, pp. 543-550.

91. Lankinen V.P., Inkeröinen M.M., Pellinen J., Hatakka A.I. Water Science and Technology, 1991, vol 24, no. 3-4, pp. 189-198.

92. Manzanares P.I, Fajardo S., Martin C. Journal of Biotechnology, 1995, vol. 43, no. 2, pp. 125-132.

93. Monje P., González-García S., Moldes D. Water research, 2010, vol. 44, issue 7, pp. 2211-2220.

94. Widsten P., Kandelbauer A. Enzyme and microbial technology, 2008, vol. 42, pp. 293-307.

95. Milstein O., Haars A., Majcherczyk A. Water Science Technology, 1988, vol. 20, no. 1, pp. 161-170.

96. Szklarz G., Leonowicz A. Phytochemistry, 1986, vol. 25, pp. 2530-2539.

97. Patent 6733673 (USA). 11.05.2004.

98. Mehna A., Bajpai P., Bajpai P. Enzyme Microbial Technol., 1995, no. 17, pp. 18-22.

99. Zhang X., Stebbing D.W., Soong G., Saddler J.N., Beatson R.P. Tappi Journal, 2002, no. 5, pp. $26-32$.

100. Demarche P., Junghanns C., Nair R.R., Agathos S.N. Biotechnology Advances, 2012, no. 30, pp. 933-953.

101. Karpukhin V.F., Faingol'd Z.L., Belov Iu.B. Obrabotka osadkov stochnykh vod: obzor. [Treatment of sewage sludge: a review]. Moscow, 1974, 64 p. (in Russ.).

102. Evilevich A.Z., Evilevich M.A. Utilizatsiia osadkov stochnykh vod. [Disposal of sewage sludge]. Leningrad, 1988, 248 p. (in Russ.).

103. Nevolin V.F., Korovin L.K. Tselliuloza. Bumaga. Karton, 1995, no. 7, pp. 29-32. (in Russ.).

104. Dul'kin D.A. Tselliuloza. Bumaga. Karton, 2009, no. 6, pp. 50-55. (in Russ.).

105. Evilevich M.A. Utilizatsiia aktivnogo ila predpriiatii tselliulozno-bumazhnoi promyshlennosti. Obzor. [Disposal of the activated sludge from pulp and paper industry. Overview]. Moscow, 1977, 47 p. (in Russ.).

106. Mikrobiologicheskaia promyshlennost' za rubezhom: Ekspress-informatsiia. [Microbiological industry abroad: Express information], 1987, no. 3, pp. 20-21. (in Russ.).

107. Bil'der Z.P., Kalishevich Iu.I. Sovremennye sposoby ochistki stochnykh vod. Obzor. [Current methods for treatment of wastewater. Overview]. Moscow, 1978, 59 p. (in Russ.).

108. Turovskii I.S. Obrabotka osadkov stochnykh vod. [Treatment of sewage sludge]. 2 ed. Moscow, 1982. 223 c. (in Russ.).

109. Romanov G.A., Semenov V.P. Mekhanicheskaia ochistka stochnykh vod tselliulozno-bumazhnykh predpriiatii. [Mechanical wastewater treatment pulp and paper mills]. Moscow, 1985. 112 c. (in Russ.).

110. Bolotova K.S., Novozhilov E.V., Sokolov O.M. Okhrana okruzhaiushchei sredy i ratsional'noe ispol'zovanie prirodnykh resursov: sbornik nauchnykh trudov. [Environmental protection and rational use of natural resources: the collection of scientific papers]. Arkhangelsk, 2007, issue 73, pp. 21-26. (in Russ.).

111. Bonilla S., Tran H., Grant D. Water research, 2015, no. 68, pp. 692-700.

112. Makarenko A.A., Garkusha I.N., Korchak G.I. Tselliuloza. Bumaga. Karton, 2004, no. 7, pp. 64-66. (in Russ.).

113. Tarasiuk V.T. Konservnaia promyshlennost' segodnia: tekhnologii, marketing, finansy. [Canning industry today: technology, marketing, finance], 2011, no. 3, pp. 55-62. (in Russ.).

114. Lund L.R., Lyford K., South C.R., Walsum P.V., Levenson K. Tappi Journal, 2007, no. 2, p. 50.

115. Marques S., Alves L., Roseiro J.C., Girio F.M. Biomass and bioenergy, 2008, no. 32, pp. 400-406.

116. Prasetyo J., Kato T., Park E.Y. Biomass and bioenergy, 2010, no. 34, pp. 1906-1913.

117. Prasetyo J., Park E.Y. Korean J. Chem. Eng., 2013, no. 30 (2), pp. 253-261.

118. Bolotova K.S. Sovershenstvovanie podgotovki osadkov stochnykh vod tselliulozno-bumazhnogo proizvodstva $k$ szhiganiiu: dis. ... kand. tekhn. nauk. [Improved training of sewage sludge pulp and paper industry to burn: the dissertation of the candidate of technical sciences]. Arkhangelsk, 2009, 118 p. (in Russ.). 
119. Larchenko V.V. Ekologiia proizvodstva, 2006, no. 4, pp. 42-45. (in Russ.).

120. Rabinovich M.L., Mel'nik M.S. Uspekhi biologicheskoi khimii, 2000, vol. 40, pp. 205-266. (in Russ.).

121. Balov A., Ashpina O. The Chemical Journal, 2012, no. 3, pp. 48-53. (in Russ.).

122. Vikman M., Itavaara M, Poutanen K. J. of Environmental Polymer Degradation, 1995, vol. 3, no. 1, pp. $23-29$.

123. Itavaara M., Siika-aho M., Viikari L. J. of Environmental Polymer Degradation, 1999, vol. 7, no. 2, pp. 67-73.

124. Khadyko I.A., Chukhchin D.G., Novozhilov E.V. Biotekhnologii v khimiko-lesnom komplekse: materialy mezhd. nauch. konfer. [Biotechnology in the Chemical-forest complex: Proceedings of the International Conference]. Arkhangelsk, 2014, pp. 310-313. (in Russ.).

125. Khadyko I.A., Kazakov Ia.V., Novozhilov E.V., Kanarskii A.V. Vestnik Kazanskogo tekhnologicheskogo universiteta, 2014, vol. 17, no. 13, pp. 277-280. (in Russ.).

126. Kozlova A.A., Varakin E.A., Chukhchin D.G. Biotekhnologii v khimiko-lesnom komplekse: materialy mezhd. nauch. konfer. [Biotechnology in the Chemical-forest complex: Proceedings of the International Conference]. Arkhangelsk, 2014, pp. 178-180. (in Russ.).

127. Varakin E.A., Khalina E.V., Rudakova V.A., Chukhchin D.G., Novozhilov E.V. Biotekhnologii v khimiko-lesnom komplekse: materialy mezhd. nauch. konfer. [Biotechnology in the Chemical-forest complex: Proceedings of the International Conference]. Arkhangelsk, 2014, pp. 99-103. (in Russ.).

128. Chukhchin D.G., Churkina Iu.V., Rudakova V.A., Varakin E.A., Khalina E.V., Novozhilov E.V. Biotekhnologii v khimiko-lesnom komplekse: materialy mezhd. nauch. konfer. [Biotechnology in the Chemical-forest complex: Proceedings of the International Conference]. Arkhangelsk, 2014, pp. 329-333. (in Russ.).

129. Rudakova V.A., Filippov I.B., Chukhchin D.G. Biotekhnologii v khimiko-lesnom komplekse: materialy mezhd. nauch. konfer. [Biotechnology in the Chemical-forest complex: Proceedings of the International Conference]. Arkhangelsk, 2014, pp. 264-267. (in Russ.).

130. Zakirov R.K, Akhmadullina F.Iu., Verbenko I.V., Sirotkin A.S. Vestnik Kazanskogo tekhnologicheskogo universiteta, 2009, no. 2, pp. 33-40. (in Russ.).

131. Aizenshtadt M.A., Bogolitsyn K.G. Khimiia rastitel'nogo syr'ia, 2009, no. 2, pp. 5-18. (in Russ.).

132. Alpeeva I.S. Anionnye peroksidazy i ikh primenenie v bioanalize: avtoref. dis. ... kand. khim.nauk. [The anionic peroxidase and their application in bioanalysis: the dissertation author's Candidate of Chemical Science]. Moscow, 2007, 28 p. (in Russ.).

133. Alpeeva I.S., Niculescu-Nistor M., Castillo Leon J., Csoregi E., Sakharov I.Yu. Proc. 18 Intern. Symp. On Bioelectrochemistry and Bioenergetics, Coimbra, Portugal, 2005, p. 123.

134. Kalatskii Iu.M., Petrova T.A., Stefanov V.E. Ekologiia i promyshlennost' Rossii, 2012, no. 12, pp. 17-21. (in Russ.).

135. Patent 2359036 (RU). 2009. (in Russ.). 
